\title{
The Sunggal War 1872-1895: In Search of East Sumatera Local Wisdom
}

\author{
${ }^{1}$ Suprayitno, ${ }^{1}$ Farida Hanum Ritonga \\ ${ }^{1}$ University of Sumatera Utara (USU), Indonesia \\ Email:nisanaceh@gmail.com
}

\begin{abstract}
The Sunggal War that occurred from 1872 to 1879 was the first war of the people against Dutch's colonialism in North Sumatera. This war was started by then Sultan Deli who gave away land concession that belongs to the leaders of Sunggal to the Dutch farming company. This enraged these leaders and started a war listed in colonial archive as "Batak Oorlog”. Historical references of the Sunggal War from Erwiza Erman, Luckman Sinar, Ratna and others are not sufficient enough in addressing local leadership issues in Sunggal in leading the army, as well as how it affects the economy and land owning pattern in East Sumatera which was the primary cause of war. The Sunggal leaders also managed to tie a coalition with the local ethnicity, among them were the Hai, Malay, Aceh and Gayo. As a result, the Dutch were forced to build the Labuhan Deli port to ease their army's activity in winning the war. In turn, Labuhan Deli had become the main contributor to East Sumatera's economic growth. The Sunggal War also gave good experience on how to handle land owning issues in the eastern prefecture. This article is a research financed by Research Board USU/BP-PTN 2016. Historical methods were used in the colonial archive in ANRI through economical and conflict approach. The issue is addressed in this article in search for local's wisdom and orally transmitted knowledge of the Sunggal War, particularly on the traditional leadership and conflict management in Deli, East Sumatera.
\end{abstract}

Keyword: local wisdom; leadership; land conflict; Sunggal War

\section{Introduction}

There are few studies on such events Sunggal War made by Tengku Luckman Sinar, Erwiza Erman, Ratna, etc. (Erwiza Erman, 1982; Sanderson, 2012: 539-544; S.L. Ray, 199; Farid Hadi Mas, 2012). Many studies have been studying and writing about the course of events of the war occurred. The research is often debate about the background of the war, the course and outcome of war. However, these studies can not reveal how local wisdom that there is in Sunggal's society like pattern Datuk Sunggal leadership, and problem solving land issues as the cause of the war.

Tengku Luckman Sinar debate on how the war, would fight to the negotiations to trap Datuk Sunggal in Arendsburg Plantation and isolation process Datuk Sunggal to Tanjung Pinang, Cilacap, and Cianjur. A similar discussion is also done by Erwiza Erman, Ratna and others. Ratna Erwiza and concluded that the main reasons for the struggles of the people Darulwustha is because plantations are causing unrest in the region Urung Sunggal. How Datuk Sunggal manages time and resolution of conflicts rooted in the land question is not much discussed. 
Therefore, it is important to broaden the scope of the study to reveal how patterns of leadership Datuk Sunggal, troubleshooting soil causing Sunggal War broke up Sunggal/Deli a safe return. With the expected disclosure of how the wisdom of the past can now be imitated by society as an important local knowledge is analyzed to answer the question of the position of today's society, especially in the North Sumatra. Indirectly Sunggal War has changed the wilderness areas of North Sumatra on a large farming area which have a direct impact on the economic development of East Sumatra at one time.

\section{The Opened Plantations and Land Conflict}

The soil fertility in Deli, North Sumatra before the arrival of Anderson in 1823 is not yet so known by the planters. Anderson describes the land in Deli; Langkat and Buluh Cina lowland is very special, with vegetable crops flourish. The lands are very rich, such as a print in black, in multiple locations, depth reaches 8 to 10 feet, ranked top in the form of clay is thick, and at the bottom is sand and gravel (John Anderson, 1971: 97). But soil fertility in Deli's become a problem as well as a disaster for the people of Deli (Sunggal). Soil fertility is then invited the farmers to expand business development of tobacco plants.

In the mid-19th century, a number of Dutch and European businessmen have opened other large tobacco plantations in East Sumatra, especially in Deli land (Jan Bremen, 1977: 48-53). Through its farms, communities of East Sumatra (Deli) was introduced with the values of modern capitalism so that there was interaction between the community and the district that has been used as the tobacco plant is also significant farm life inhabited by Europeans. This interaction actually takes place in an atmosphere that is not balanced, between two social systems are completely different. These interactions are initially gave rise to tensions between the communities of East Sumatra (Deli) with migrants/planters people of Europe, particularly the Dutch and also with the Sultan of Deli. Tension often occurs due to the many farmers seize and take the land concessions that traditionally have belonged to the Datuk's/Urung independent king.

The success of the company's farm in search of land suitable for their political support of Sultan Deli and the Dutch colonial government. The Dutch government and the Sultan of Deli have its own importance. The Dutch government is also trying to create the North Sumatra/ Deli into the production of commodities trading to the European market. This objective is in line with the open door policy (OpenDoor politiek) running the Dutch government from 1870, (Opendoor Politic) carried out with the purpose of looking for foreign investors to invest in the plantation industry in Indonesia.

The achieve that big there are two important decisions taken by the colonial government: first, apply the Agrarian Law of 1870 as law enforcement to obtain land concessions and keep the "rust en orde" (stability security) in the Dutch East Indies, including Deli, Sultan also has economic and political interests of the plantation development in the North East. Economically, most of the money that is available for rent has helped raise its prestige and influence as well as the legal and political territory he is recognized by the Dutch government. These efforts have been carried out before the arrival of the Dutch by the Sultanate of Deli both peaceful (political marriage) and violence (war 1822) for control of the area Darulwustha (Ratna, 2012: 539-540). 
But behind the big clash between the two powers (Holland \& Deli) have been causing havoc to the Sunggal people. Datuk Sunggal not involved in the lease of land and this is what led to open conflict with the Dutch government. This conflict is the cause of the occurrence of a direct relationship between the community and traditional crops with modern economic systems/capitalism. Open conflict between the people of the Dutch and Sunggal War took place on May 15, 1872, after two years of Agrarian Laws enforced in the Dutch East Indies. This issue proves that the conflict was clearly nothing to do with the land issue. According to the first owner of the farm, basically the local authorities are in fact ordinary people are not dissimilar to the population. Their power is limited, but then become big after handing land to the entrepreneurs Europe for use in the long term, they took possession of the land which they have not previously (Jan Bremen, 1977: 22).

The success of European investors in tobacco farming industry appears to wreak havoc sunggal society. Sunggal Deli relationship with an already strained since 1822 Darulwustha Deli attack now it's getting worse. The problem is that, most of the lands handed over by the Sultan of Deli to employers' blade is Darulwustha territories and even into the territory of Datuk Sepuluh Dua Kuta and Datuk Sukapiring. Sultan Deli action has caused unease and opposition people. Various complaints and appeals filed were not considered by the Sultan of Deli. Even in 1870, the Sultan of Deli again gave land concessions to companies De Rotterdam. People are prohibited from planting tobacco and other crops, while the land they already have for centuries from generation to generation, finally Deli and Sunggal relations increasingly strained.

The addition, the Datuk Sunggal and the local population was also not happy with the presence of the Chinese people on the farms who entered the Sunggal territory because their presence was threatening the economic development of the people Sunggal and damaging public morals. As was stated by Datuk Kecil while imprisoned in Prison Tanjung Pinang, Riau,

They do not agree that the fertile soil of distributed granted by the Sultan of Deli for impunity toDutch planters. The existence of farms is also Dutch, the Chinese entered the throng which was then given parakan monopolies of salt, opium and gambling places open everywhere. For example, the sale price of opium in Sunggal from \$ 50 to \$ 600 in two years. "(Tengku Luckman Sinar, 1996: 32)

However, the actual reason for the cultural conflict can be explained is due to the rapid changes in the Deli. Than 1864, relations began to interfere traditional middle sistema development of commercial capitalism. The change is even faster than what is expected of indigenous peoples. As a result, when in other areas, progress gradually accepted by society. And at the Deli, the change is so fast, to the detriment of the traditional political system (Politiek Verslag, 1872: 61). Thus, the strong influence of the colonial bureaucracy that affects the socio-economic-political structure of the earth's sons, the worse the conflict or tension occurs. "The Datuk-Datuk Urung unhappy over the Sultan of Deli expand plantations and invaded the land of the population resulted in a loss of income. At the end of 1871, they frequently held a private meeting in Sunggal regards discuss stal their position in the territories of the empire Deli and regional Urung the smakin affected on their right to lease the land acquired by the Sultan of the farmers and what about the legislative powers of the Datuk's Urung against Chinese people who live in their territory (Erwiza, 1982: 79-80).

Open conflict between the people Sunggal and Sultan Deli with Dutch finally broke out from May 1872 to Datuk Kecil, Datuk Jalil and Sulong Barat as a rebel leader arrested 
then thrown by the Dutch to Cilacap in November 1872 (Letter of Lieutenant Colonel Van Stuwe, January 19, 1874). According to official reports the Department of Defense Indies at the date of 4 November 1872, the Dutch military casualties were 31 people and injured as many as 592. This number does not include victims of manga and fraternal forces of Sultan Deli and farm workers (W. Hogemboom, 1874: 265-266). After Datuk Kecil, Datuk Jalil and Sulong Barat thrown into Java, the situation in Deli in 1873 generally safe return. The contracts for the company's farm land back briskly with greater concern for the welfare and well-being of the indigenous population. Land lease contracts - contracts made by the operator of the Europeans as a whole have been allocated to the mayor four quarters in Deli smelling the land is still considered to be entering its territory. At the date of June 14, 1873, this regulation is strengthened by a new act. The leaders of the Batak Karo involved in the war have been granted amnesty, but they are still waiting for peace ceremony took place in accordance with the custom of Karo as a sign of peace (Politiek Verslag, 1873: 8-10).

The Sunggal initial resistance of the people can finally be resolved through the recognition of customary rights (communal land) local people's. Sultan Deli also ready land concession revenue it receives. Resident Netherlands also set three equal parts to the Sultan of Deli, the Datuk Penghulu Batak Karo. Each will receive 1/3 of (Deli ", ENI, II, 1917: 578). Even so land position (customary) Sunggal people, especially the Malays in the concession continue to be debated. In the first concession granted in 1864 to mask Nienhuijs not include conditions on the rights of the people. Only in 1877 began with the concession contract model. But there is still no regulation for both the locals and the concessionaire. Giving concessions to the Dutch businessman raises questions in terms of the law to the people of the land, both for metastasis (farming) or take forest products and so on. The 1877 Concession finally reviewed and in 1878 for the first time in the concession agreement are the terms of the concession holder's obligations to provide lands for local resident's gardens. In clause 6 of the concession was mentioned, "if the boundaries of the land referred to in clause 1 of this agreement are the people, the land they use, own the farm, plus the land as needed as a replacement to an area of four shoulder ( 1 shoulder equivalent of 0.9 ha) for every regular people can use them independently. The position of the land rights of indigenous people continues to be a serious problem in the future as in the concession in 1884, 1892 and so on until the end of Dutch colonial rule and even more serious in the postcolonial era. Returns customary rights lands in Deli been the cause of strife have taken a long time sorta exhausting groups of people involved (Edy Ikhsan, 23 February 2011). The issue of customary rights to land in Deli also does not stop at the concession only. Anxiety and social tensions continue to threaten the planters and the Dutch government started the war with the people act Sunggal second stage.

The trio Datuk Urung Sunggal frail it was sent by Dutch goverment. Nonetheless, the level of security in the restive Deli back against security threats to European farmers and officials of the Dutch. In May 1873, there was information that says that a number of calls from Aceh people living in the border of Langkat Hulu (Upper) have received a letter from the Sultan's call to rise up against the Dutch. Such letters begin to be distributed to Kampung Sitelu Kuru (Gadjah) where the origin of kings Urung Sunggal/Serbanyaman. News of this reached the ears of the farmers and the increasingly worrying situation with the presence of some 10,000 people opposing Deli and fraternal on going down to Deli Downstairs weeks to attack the peoples of Europe. Apparently the news was deliberately exaggerated, so that the Dutch cancel the action to send military aid from Tanjung Pinang. But security officials made Kroesen busy with a visit to the area and an investigation is Upper Langkat. 
The news was exaggerated, but the level of security at the Deli, especially the safety of Europe's planter and the blade is not fully secure. Datuk Badiuzzazman, after Datuk Kecil, Datuk Jalil and Sulong Barat was arrested later acted secretly to continue the fight by attacking the guerrillas to ease the warehouses of tobacco belonging to the farmers of Europe with the aim of creating a state of insecurity to farmers of Europe with his family until they stop work dankawasan surrounding farms. Tobacco stored in warehouses ready for diersoort but it burned in retaliation against the confiscation of people's lands by the Sunggal farmers' tobacco plants to be protected against Dutch security forces. Each tobacco warehouse that will be attacked and burned ditempal advance with the customary "banyan enemy". A meeting between the Dutch Assistant Resident in Siak, Locker de Bruijn, the Sultan of Deli, and Datuk-Datuk Empat Suku in April 1873, Locker de Bruijn expressly reminded Datuk Badiuzzazman when there was still disruption to security in the region, then the cube to be responsible is Datuk Bediuzzaman (Tengku Luckman Sinar, 1996: 34). The meeting was conducted as security in return Sunggal disturbed, let alone the loss of the trade delegation of Sultan Deli whereabouts are unknown. This incident proves that the opposition has not stopped people Sunggal even against the spirit alive and to be raised by Datuk Bediuzzaman.

Resistance under the leadership of Datuk Bediuzzaman and his brother Datuk Alang Muhammad Bahar was conducted in secret often done with community leaders in several places, including in Kampung Pagar Batu/Pancur Batu. During the meeting, they still do not want to acknowledge the authority of the Sultan of Deli on Darulwustha and then discuss strategic attacks on farms. Activity attacked and burned warehouses were headed by his younger brother Datuk Alang Muhammad Bahar. The situation is getting desperate Deli with hunger issues. This situation occurs because of a boycott among farmers who sympathized with the struggle Datuk sunggal to not want to sell their rice to the Netherlands. As a result the Netherlands had to import rice from Ranggon.

In 1866, the movement attacked tobacco plantations continue to apply. Schadee reported that there is the owner of the farm with his family in a few killed. Those who survived were panicked and fled to Medan. The movement against the increasingly widespread, so that almost all Europeans warehouse owned farms can not be saved. A year later, in Ogod 1876, Mr. Van Der Sluis Cs, a farm owner in Sungai Tawar located in fraternal Babalan, Langkat was attacked by Gayo people injured and caused him to her house burned. A month later in September 1876, Tandem farm property near the Sungai Diski, Mr. Peyer en Van Gulich was impugned Gayo people. In the attack a European workers were killed and several people were injured. In October 1876 also, a knife in Sungai Diski was attacked by the people of Kampung Sialang Moeda. J. Lohmann farm owner's wife and two sons were going to die and there are other households have been injured. The Dutch governments take immediate action to protect farms. Immediate action was successfully capture the attackers were four people Batak Karo, two Malays were shot dead and six people were sentenced to forced labor. Its main leader was named Razali to investigation; it turns out the attacks carried out by order of the Panglima Selan, a Batak Karo that influence the way among those Gayo based in Si Umpih-Umpih (about 10 hours drive from Timbang Langkat). He is often triggered chaos and act to raise a number of his followers to attack the farm Ajer Tawar. In November 1887, his camp was attacked by the Dutch armed forces but Panglima Selan and his followers managed to leave the camps (W.H.M. Schadee, 1919: 16-17 \& 108). However, all material evidence by the Dutch is the result of a seizure attack earlier in the Diski. The attack carried out by the Panglima Selian actually is part of the continuation of the struggle against Dutch colonialism Datuk Bediuzzaman after Datuk Kecil, Datuk Jalil and Sulong 
Barat was arrested and exiled by the Dutch into Java. Panglima Selian actually the nephew Datuk Alang Bahar. Therefore, it is clear that all action attacking and burning farms in Tandem, Sungai Mencirim, Diski, Gedong Johor and attacks against Dutch forces on the orders of his brother Datuk Badiuzzazman and Datuk Alang Bahar (Muhammad Hitam, April 29, 1983).

The effect of frequent attacks on farms, the Dutch began to plan and launch strategy Christianisation through the motions Bible Dutch (Zending) to divide the Malays fraternal relations with Karo Sunggal. They also expedite the activities of missionaries to restrict the influence of Malay/Muslim among the Batak Karo non-Muslims. The existence of the act of breaking the union between Malays and Karo is also clearly visible in any reports of the Dutch colonial government frequently mentioned the attacks on farms conducted by the Batak, but not mentioned as Karo. Basic glassware does not work even unity among the Karo/Malay Batak Karo sunggal to grow stronger in the mountains to keep trying to liberate their territory from Dutch colonial rule.

The action of burning tobacco warehouses and create havoc in the farms and in general has decreased townsman economic development of the Dutch East Hindia's. Netherlands finally trying hard to overcome the attacks and acts of sabotage, including the spies who were brought in secretly to Sunggal and it worked. Referring to a confidential document, found a female spy, named Lela has reported that the real mastermind of attacks on warehouses of tobacco is Datuk Badiuzzazman. For that reason in a meeting in 1894, which aims to find a way out of the crisis in Deli, Dutch Assistant Resident in Siak has proposed that Datuk Badiuzzazman soon came to Batavia to meet Governor General. This proposal was accepted Datuk Badiuzzazman without suspicion.

Datuk Badiuzzazman was accompanied by his younger brother Datuk Alang Mohammad Bahar, Datuk Mahmud and Daim went to Batavia to leave a family member in Sunggal. Upon arriving in Batavia, Datuk Badiuzzazman unable to meet with the Governor General and the same time is not allowed for a return to Sunggal. An individual who acts as a mediator has to meet and express the truth that they have become an outcast. Datuk Badiuzzazman recently realized that they had been deceived by the Dutch. They can be helped with the terms of asking forgiveness for his mistakes $n$ in the Dutch Queen's birthday. But Datuk Badiuzzazman adamant and did not change his stance that he will not ask for forgiveness from the Dutchs to death because it was a four-expensive ancestors. Finally, Datuk Badiuzzazman and his brother Datuk Mohd Alang are collins was imprisoned in Bengkalis, Riau. Then through the Governor General Decree No. 3 on the date of January 20, 1895, they were sentenced to banishment for life. Datuk Badiuzzazman was exiled to Cianjur and Alang Datuk Mohd. Bahar was thrown into Banyumas. This news has caused people for 3 months Darulwustha mourning as a mark of respect and loyalty to their leader. During Friday prayers, they pray for the people's fighters for three consecutive months (Akhtar Bay, 1973).

The situation experienced by his uncle, Datuk Kecil and Datuk Mohammad Jalil, Datuk Badiuzzazman also did not get a chance to see isetri children and other family members that died in exile. Datuk Bediuzzaman was buried in the village of Pue, district of Cianjur, Cianjur, West Java province and local communities tomb known as the "Tomb of Sultan Deli" and his brother, Datuk Alang Mohd. Bahar was buried in the Desa Lampui, Jombang district, Banyumas, Central Java (Prisma, 1980: 37).

\section{Datuk Sunggal Leadership}


The Sunggal public support for resistance against the Dutch was great. This was evidenced by the contribution in kind of every household in Sunggal of 2-10 dollars used for war preparation base defense (Letter Schiff to the Gouverneur General, May 7, 1872). The Sunggal fighters also subsequently posting a notice of war according to the custom of Karo named as "enemy banyan" in certain places which stated that those in favor of the Sultan Deli and the Dutch will be burned.

The role of Datuk Kecil, Datuk Jalil and Sulong Barat as a commander directly mobilized armies and people in the field of energy with various preparations. Weights made fraternal bull defense by military force reinforced with 1,500 people. Even standing in Kejeruan Selesai and Bohorok in Langkat are further strengthened. This position is relatively easy because there is no family relationship between the rulers Sunggal with both of these places, for example the wife of Datuk Kecil and Datuk Jalil is denko catty of Kejeruan Selesai. The strength of the combatants Sunggal already reached 1000 Karo's people and 500 peoples with the Malays. Most of them have been equipped with guns (rifles piston rod).

The Karo community support is not only of Sunggal, but also of Karo Highlands. The Kings Sunggal is Surbakti descent from Kampung Gajah in Karo land, it is not surprising that people with a love of Datuk Sunggal so, too high. With the thought that people, descendants Surbakti itnggi has a value other than the Karoyang especially since Datuk Sunggal take a stand against Dutch colonial rule. The Karo Highlands society also has its own strategy and how to provide assistance to the fight Datuk sunggal. According Looks Sebayang (June 5, 2006), he is descended directly from Pangaring Sebayang an assistant Nabanung Surbakti. He struggles to get information about Datuk Badiuzzazman through stories handed down from grandfather. There are 6 lines of the struggle that has traditionally been used by the Karo people. Pass this fight is actually also a cultural and trade routes traditionally used by people with long ago to trade and establish fraternal relations with their relatives in the area Deli, fraternal, Serdang and Aceh. Route struggle in detail is as follows:

1. Desa Gadjah (Kampung Surbakti)-Kawar-Pamah Sembilir-Telagah-ke Langkat/Binjai

2. Lau Sigedang- follow Sungai Bingai flows- directly into the Subekan-Tanduk Benuato Binjai

3. Sibolangit-to Tanduk Benua

4. Sembahe-to Tanduk Benua

5. Talun Kenas- Deli Tua-Rumah Bacang- Pancur Batu- Sungai Belawan- Tanjung Selamat - to Sunggal.

6. Tamiang (Aceh)-Berandan-Tajung Pura-Binjai-Namu Ukur-Tanjung Gunung-SawitSubeikan- Tanduk Benua.

This is the path of struggle used by Sunggal fighters in helping the fight against the Dutch. Through this route, assistance in the form of soldiers/troops and logistics. The one team of Tanah Karo is Saving Surbakti (Pulu Jumaraja), Pa Blegah and Pa Tolong. Nabung Surbakti has an assistant named Pangaring (Rasyid) Sebayang. This one of his duties as a presenter of information about the location of struggle and battle. In addition, there is also a relay that information to impersonate salter (perlanja sira). Their role in the Sunggal War to deliver a confidential letter is so important and valuable to the Karo people's. In this way, Datuk Sunggal get in touch with all the teams that are Sunggal fighters in Aceh, Tanah Karo, Langkat and Serdang so successful assistance and logistics team.

The preparations for the attack was planned and so long just waiting for the appropriate time. Information from the Chinese named Anton (opium traders) who were 
arrested by Datuk Sunggal and then released has said that the masses were ready with a complete arsenal led by Panglima Dalam Sunggal. This was explained that the Datuk Bediuzzaman connected directly to Datuk Jalil and Datuk Kecil by letters (Politiek Verslag, 1872: 1). The report from Deems officers dated June 12, 1872, Datuk Jalil, Sulong Barat, Sulong Putra, Bintang Siak, Wan Musa from Sinembah and Tengku Sulong Hebar children's is also involved in the preparations concerned. The Bahorok, Stabat Tan Mahidin area and the Batak of Langkat upstream also supports the Sunggal fighters after they held a rally in Tanjung Jati (Tengku Luckman Sinar, 1996: 12). Meanwhile the Sunggal fighters start acting burning tobacco warehouses and homes of the Dutch master blade. The effect of tobacco production has dibehentikan. The foreign farmers have fled with their families to the port Deli. At that time, Sunggal to be in a state of unrest. Resident of Riau Schifft been reported to the Governor General in Batavia that he had received a letter from the owner of a plantation in Deli named Hagge Lies, who said the fighters Darulwustha has entered Langkat and Deli and a total of 40 families lords garden of Deli and fraternal been expelled to port (Tengku Luckman Sinar, 1996: 11). In April 1872, Mr. Tunick also reported that workers Tuan N.H. Incandescent Schlatte and that is building the road to fraternal had to stop their work because it is threatened by a group of 40 people Batak Karo who received orders from Datuk Sunggal (Politiek Verslag, 1872: 4).

The personal meeting between the Sultan of Deli, Chatham Naval Commander and Officers Deems have known that since August 1871, the region has actually Sunggal have a plans to oppose the rule of the Sultan Deli and plantation companies. The plans was lead by Datuk Badiuzzazman with strong support from the Datuk Kecil and his brother Datuk Jalil, who sought independence Sunggal from the Deli and and Langkat though he was already old (Politiek Verslag 1872: 6-7).

The Sultan of Deli also been trying to persuade Datuk Sunggal, Datuk Jalil and Datuk Kecil but failed. The Datuk's of Sunggal acting declined the invitation of Sultan Deli to negotiate reason that Sunggal is his homeland and he did not have any dealings whatever with the Sultan of Deli, and even act protested against Officer Deems that prohibits the entry of machinery and tin (Tengku Luckman Sinar, 1996: 11 ). Sultan Deli and 400 Dutch guilders has been offered to anyone who berjawa catch people Darulwustha Datuk Kecil (Mahini Surbakti), Datuk Sulong Jalil and Sulong Barat. The offer was ignored. This action shows that the leadership of Datuk Sunggal is strongly supported by the people. Despite his frail but still consistent to fight for the rights of the people Darulwustha even had to deal with the Dutch armed forces.

The Datuk Sunggal was indeed charisma of a leader, even if not supported by backmystical elements but only with a consistent attitude and personality to fight for the interests of its citizens. A words therefore reasonable the Sunggal's people very sad and disappointed when they come out of the den for the invitation to negotiate with the Dutch in Klumpang on October 25, 1872. The residents scrambling to find their ancestors. Leadership Datuk Sunggal so important in moving energy and morale of the population, for that reason he is highly respected. Furthermore there is a link between their relatives in order to establish cooperation across ethnic war with the Dutch army.

In December 1871, Datuk Badiuzzaman Surbakti as the King Urung Sunggal/ Serbanyaman and all the relatives and those of his right including Karo Batak people of the mountains have held a rally in a pepper plantations. The rally was attended by the Datuk Kecil (Mahini), Datuk Jalil, Datuk Sulong Barat, Nabung Surbakti as commander of the mountains 
and Tuanku Hashim represents Panglima Nyak Makam as commander of the Aceh military troops, Alas and Gayo.

The assembly has decided to launch an attack and war against the Sultan of Deli and the Dutch government. Datuk Sunggal Bediuzzaman says that "disputes between us during this take away from the mind and let us together against the Dutch who want to seize our land". Datuk Kecil said "if we do not get, we will be driven out of Dutch" and the West Sulong also states that 'the Dutchs and the Sultan of Deli mere three-quarter money, depriving people of land for its own sake. "The conclusion of the assembly is as follows;

1. Sunggal, Karo and Aceh (Alas, Gayo) agreed to build unity and all disputes conducted Dutchs through divide and rule policy should be terminated.

2. Sunggal, Karo, and Aceh (Alas, Gayo) agreed the Dutchs and defending every inch of the land to the public.

3. Sunggal. Karo and Aceh (Alas, Gayo jointly repel any invaders who colonized the region (H. Biak Ersada Ginting, 2002: 36-37).

The result of that meeting was realized with the creation of a movement body centered in Kampung Gajah/Sitelu Kuru Tanah Karo. The movement body to organize the army that consists of a powerful man and has a high mysticism and prepare other logistics. The agency is headed by Datuk Mahini (Kecil) with meletakkaan representative in Tanah Karo. The agency is directly responsible to the Datuk Bediuzzaman. The Sunggal people's assigned to manage this body organizations in Kampung Gadjah are Muslim. During their stint in Kampung Gajah, they met with the brothers descended Surbakti.

The shape of the cross-ethnic cooperation conducted by the Datuk's Sunggal has existed for a long time through a process of extension you are as described in the previous section. The relations Karo society in particular with Aceh especially Gayo and Alas is a form of brotherhood that is influenced by the geographical position is hardly allow Datuk Sunggal successfully against Dutch colonialism. The existence of cross-ethnic cooperation in the Dutch has received special attention from Batavia. The Dutch acts send armed forces from Batavia. Cross-ethnic cooperation is also successful to bring together the people who are ready to help to carry out attacks against the Dutch.

\section{Conclusion}

Sunggal War is over about 144 years ago, leaving a painful memory for the people Sunggal. This war is studied, by the author, not to recall the course of the war, but to take lessons. There are two important lessons that can be drawn from this story Sunggal War. First, Sunggal War is shaped land conflicts which first occurred in North Sumatra. This incident is the first protest of the people of North Sumatra to the Dutch colonial presence in the North. There lecturer of this story is important, how best to manage land issues in the North. These events may datas by the Dutch, not only by removing the leaders driving to Java, but more important is to solve the root of the problem is related to neglect people's rights by the Sultan of Deli Sunggal, planters and the Dutch East Hindia's government. Therefore, Dutch Resident's have established three equal parts, with Sultan, the Datuk's and Penghulu's Batak Karo. Each received 1/3 share of the concession of land leased to the planters. This indirectly has solved the problem, but it has become a gateway to the colonial authorities and farmers to understand the people's rights to their ancestral lands. Evidently then, people Darulwustha 
officially recognized customary rights in concessions in 1878 with the decision of the Dutch gave 4 shoulder ( $3.6 \mathrm{ha}$ ) for the purpose of agricultural land. The contracts of land cultivated for its knives start back with more focus being of the indigenous population. Land lease contracts - contracts made by the operator of the Europeans as a whole have been allocated to the Datuk's Empat Suku in Deli, throughout the lands it while entering their territory.

Second, War Sunggal, the colonial government had put Deli Port landing sites and Dutch troops in Deli, East Sumatra in order to put people Sunggal. The Deli Port become more effective and strategic replace Penang port which has been used by the Dutch. The action eventually substantially affect the State to economic development in East Sumatra.

Third, Perang Sunggal left interesting notes about how a leader acts in dealing with community issues. Datuk's Sunggal have shown how a person becomes a responsible leader, had a consistent attitude in the fight for the sovereignty of the people (indigenous rights, culture and land people) despite being ill and had to deal with the armed forces of the Dutch's later exiled to death in Cilacap and Cianjur, Java Island. His attitude was gained tremendous respect from the people of Sunggal, even if they were offered a total of 400 guilders from Dutch. Correspondingly Datuk Sunggal was a great leader who is able to handle the combined traffic and ethnic groups in mustering forces against the Dutch in North Sumatra.

\section{References}

Anderson, John. Mission to East Coast of Sumatra in 1823, London: Oxford University Press, 1971.

Bremen, Jan. Menjinakkan Sang Kuli: Politik Kolonial pada Awal Abad Ke-20. Jakarta: Pustaka Grafiti, 1977.

Datuk Akhtar Bey. "Taromba dan Sejarah Keluarga Besar Puak Sunggal/Serbanyaman",. Medan: t.tp, 1973.

Ginting, H. Biak Ersada. Sejarah Perjuangan Suku Karo Dan Dari Perang Medan Area Hingga Sipirok Area, First Edition. Medan: Ravi Bina, 2002.

Michael van Langenberg, "National Revolution in North Sumatra: Sumatera Timur and Tapanuli 1942-1950", Doctoral Dissertation, University of Sidney, 1976.

Pelzer, Karl, Planter and Peasent: Colonial policy and The agrarian struggle in EastSumatra 1863-1947, s'Gravenhage, 1978. Trans. Toean Keboen dan Petani: Politik Kolonial dan Perjuangan Agraria di Sumatera Timur1863-1947, Jakarta: Sinar Harapan, 1985.

Ratna. Aceh, "Deli dan Perang Sunggal". Papers in Perang Sunggal Seminars, Medan, 2004. , "Sumatera Utara Bergolak (1872-1904)", in Indonesia dalam Arus Sejarah: Kolonisasi dan Perlawanan, Jilid IV, Bandung: Icktiar Baru van Hoeve, 2011.

Stoler, Ann Laura. Kapitalisme dan Konfrontasi di Sabuk Perkebunan Sumatera, 1870-1979. Yogyakarta: Karsa, 2005.

Schadee, W.H.M. Geschiedenis van Sumatra's Oostkust deel I. Amsterdam: Ooskust van Sumatra Instituut, 1919.

T. Ibrahim Alfian. "Kiras Bangun (Garamata) Pejuang Dari Tanah Karo". Papers in Garamata Seminars, 2003.

T. Luckman Sinar. Sari Sedjarah Serdang, Djilid I, Medan: 1971. ,. Perang Sunggal 1872-1895, Second Edition. Medan: No. Publ. 1996. 
Vlekke, Benard H.M. Nusantara Sejarah Indonesia. Kuala Lumpur: Dewan Bahasa Pustaka \& Kementeraian Pelajaran Malaysia, 1967.

W. Hogemboom, Kridjsbedrijven van het Rechter half 11 de Batalion Infantrie in het Rijk van den Sultan van Deli van den 11 den July tot den 6 November 1872, Militaire Spectator, 3e serie 19e deel 1874.

Jeeger, F.A.W. "De Expeditie naar Deli"

Politiek Verslag Residen Riau, 1872.

Politiek Verslag Residen Riau, 1873.

The Letters Assisten Riau, Locker de Bruijne to Resident Riau, Nomor LaE4, November 9, 1872.

The Letters Resident Riau to Gouverneur General te Batavia, No. 1539/1, June 22, 1872.

The Letters Resident Riau to Gouverneur General te Batavia, No. 1409/1, June 3, 1872

The Letters Resident Riau to Comand Comander Military Riau Area in Tanjung Pinang, No. 1182/1, May 6, 1872.

The Letters Resident Riau (Schiff) to Gouverneur General te Batavia, No. 1184/1, May 7 , 1872.

Inventaris Arsip Riouw No. 142. 